\title{
Eportfolio, Alternative Assessment and Student Self-Assessment: Exploration of the Correlation in Primary Education
}

\author{
Aggelos Haralabous (Corresponding author) \\ Primary education school teacher \\ Tsiller 15-17, 11144, Athens, Greece
}

Tel: 30-369-781-38491Ｅ-mail: aharalabous@gmail.com

\author{
Maria Darra \\ Assistant Professor, University of Aegean \\ Dimokratias 1, $7^{\text {th }}$ March Building, 85100, Rhodes, Greece \\ Tel: 30-693-242-5804_E-mail: darra@aegean.gr
}

Received: April 28, 2018 Accepted: May 27, $2018 \quad$ Published: June 5, 2018

doi:10.5296/ijld.v8i2.13097ＵRL: https://doi.org/10.5296/ijld.v8i2.13097

\begin{abstract}
The main purpose of this study is to explore and register the trends and perceptions of primary school teachers about the implementation of the eportfolio as an alternative form of student assessment and as a tool for self-assessment by students. The survey was carried out during the second semester of the school year 2016-2017 using the anonymous written questionnaire method, which was answered by 215 primary school teachers of all subjects from the first educational area of Athens, the capital of Greece. The results of the survey show that most respondents believe that it is necessary to completely change the existing student assessment system, to apply alternative forms of assessment and to abolish the quantitative assessment. Regarding the exploration of the eportfolio for students' evaluation and self-evaluation, the respondents in their overwhelming majority state that they have little or no knowledge of the subject. Also, they state that they do not apply at all or make little use of the eportfolio, although two thirds of the teachers consider that eportfolio's practical application quite important as an alternative form of assessment and self-assessment of the student.
\end{abstract}

Keywords: Eportfolio, alternative forms of student assessment, student self-assessment, 
Information and Communication Technology (ICT)

\section{Introduction}

The issue of students' assessment constitutes one of the major questions in education (Konstantinou, 1998). At the same time, the integration of Information and Communication Technology (ICT) in the educational progress constitutes a concrete objective in all modern educational systems. The eportfolio, the digital publication of traditional portfolio, constitutes $(\varepsilon \pi \alpha v \alpha ́ \lambda \eta \psi \eta)$ a new approach of authentic evaluation (Barrett \& Knezek, 2003), which is based on the Information and Communication Technology (ICT) and included in the alternative forms of evaluation (Lorenzo \& Ittelson, 2005a; Papathanasiou \& Manousou, 2011).

From the research and study of relative bibliography in regard to the eportfolio implementation in education the relevant surveys are summarized in:

a). the theoretical background of the eportfolio (Abrami \& Barrett, 2005; Lorenzo \& Ittleson, 2005a), the benefits of its adjustment (Barrett, 2007; Heath, 2005; Canada, 2002; Love \& Cooper, 2004; Abrami \& Barrett, 2005; Wade et al., 2005; Wall, Higgins, Miller, \& Packard, 2006), its differences with traditional portfolios (Barrett \& Knezek, 2003; Challis, 2005; Abrami \& Barrett, 2005; Strudler \& Wetzel, 2005), and implementation proposals (Doukakis, 2006; Papaharalabous, 2008; Papathanasiou \& Manousou, 2011).

b). its practice to university education, either as a pilot practice or by recording students' and professors' views (Tosh, Light, Fleming, \& Haywood, 2005; Knight, Hakel, \& Gromko, 2006; Coutinho \& Bottentuit, 2008b; Ritzhaupt, Singh, \& Seyferth, 2008; Hallam \& Creagh, 2010; Beresford \& Cobham, 2011).

c). eportfolio's use both by primary education students (Sofos \& Liapi, 2007) and secondary education students (MOSEP, 2007; Papathanasiou \& Manousou, 2011).

d). Mahara's system practice (Nikolou \& Georgopoulos, 2012; Sotiropoulos, 2012) and other similar systems (Stylianou, 2013).

In addition, in recent years, Information and Communication Technology (ICT) have gained increasing ground in Greek educational reality either by being introduced as a separate course in the primary education, by software in various subject areas (Kelesidis et al., 2016), or by creating a digital repository called Photodentro LOR (Greek National Learning Object Repository, http://photodentro.edu.gr/). Of course, it is a common belief that the evolution of Information and Communication Technology (ICT) in Greece takes place slowly compared to other countries of the European Union. However, all the above changes are significant and promising, bearing in mind that the teacher is the key factor who is required to implement any changes proposed each time (Craig, 2003). In the international but mainly in the domestic literature, there are no recorded surveys of primary teachers regarding their views on the use of eportfolio in education let alone in the assessment process. Most research at the international level is mainly focused in the field of higher education, although in many countries (USA, England, Australia) organizations have been set up to promote eportfolio at 
all levels of education. The Greek bibliography records research on the application of the eportfolio (Sofos \& Liapi, 2007; Papathanasiou \& Manousou, 2011; Tsoutsou \& Bertsou, 2013). However, there are few studies investigating the views of teachers on eportfolio and its practice both in Greece and internationally (Coutinho \& Bottentuit, 2008b; Parker et al., 2012a). In this context, it is important to explore teachers' views on the existing form of student assessment as well as the use of the eportfolio as an assessment and self-assessment tool for students. This is the aim of this paper. Achieving the above objectives through the recording of teachers' views is very vital and can help to extract useful conclusions regarding the possibilities of applying alternative forms of student assessment, such as eportfolio to the Greek educational reality and the use of eportfolio as an assessment and student self-assessment tool.

\section{Literature Review}

The eportfolio has been a field of research in recent years, where many studies have been conducted, mainly at international level, clarifying what it is, how and which way we can use it at all levels of education, what its benefits and the benefits of its implementation are and its differences with traditional portfolios.

In Greece, research focuses on the theoretical approach of the eportfolio (Doukakis, 2006), on softwares and applications for the development of eportfolio (Papacharalambous, 2008, Nikolou \& Georgopoulou, 2012; Sotiropoulou, 2012; Stylianou, 2013) resulting from the application of the eportfolio. There are also surveys that record teachers' perceptions and attitudes about the traditional portfolio (Paroutsas, 2011), those from students from primary school (Tsoutsou \& Birtsos, 2013), as well as surveys that have taken place in students' primary education, where the eportfolio was implemented (Sofos \& Liapis, 2007) but also to secondary school students (Papathanasiou \& Manousou, 2011). The above surveys list both the advantages of implementing the eportfolio and the difficulties that arise from its implementation. In addition, the aforementioned surveys, concerning both primary and secondary school teachers, have demonstrated teacher ignorance of the eportfolio and the difficulties in its implementation.

In the international arena there are many organizations (EIfEL, BECTA, MOSEP, AAC \& U, AAEBL, eportfolio California, eportfolios Australia) which deal with eportfolio and its implementation by conducting many researches in collaboration with researchers (Ritzhaupt et al., 2008), colleges and schools of all levels of education. The majority of them concern higher education and the practical application of the eportfolio to college and university students (Tosh \& Light, 2005; Knight et al., 2006; Coutinho \& Bottentuit, 2008b; Hallam \& Creagh, 2010; Maher \& Gerbic, 2009; Bolliger \& Shepherd, 2010; Buzzetto-More, 2010; Garrett, 2011; Thanaraj, 2012; Klampfer \& Köhler, 2013; McWhorter et al., 2013; Hsieh, Lee, \& Chen, 2015; Landis, Scott, \& Kahn, 2015; Wuetherick \& Dickinson, 2015; Nor Azlan, Amin, \& Mohd, 2015; Mason \& Williams, 2016). These surveys conclude that there are benefits from the use of eportfolios in higher education while pointing out the student's perspective as important for the success of its implementation. Also, there are two surveys that concern teachers (Coutinho \& Bottentuit, 2008b; Parker, Ndoye, \& Ritzhaupt, 2012). The 
first survey show that teachers appreciate learning experience and feel more responsible for the preparation of learning opportunities facilitated by technology, learning and student communication. Regarding the second survey on the use of the eportfolio in a Teacher Education Program, the findings suggest that eportfolios provide improved and up-to-date information about easily accessible and organized teacher educators.

\section{Theoretical Background}

The eportfolio can be defined as a collection of digital objects that can include: documents, photos, videos, music composition, presentations, exercises solutions designed to support a range of pedagogical processes and evaluation purposes that are posted on websites, or providers specializing in eportfolios. It is essentially the electronic version of the traditional portfolio. It is a product created by student learners who decide what to include in their content (Abrami \& Barrett, 2005; Lorenzo \& Ittleson, 2005a).

The eportfolio is based on the following basic principles: a. student - centered active learning, reflection, development of metacognitive skills, b. the development of students' interest in new technologies, c. the development of increased responsibility, documentation and organization of their work; and d. the emphasis on integrated and experiential learning. All of the above is intended to support a range of pedagogical processes and to facilitate assessment, while developing self-assessment and peer assessment. The eportfolio, depending on the use and purpose it serves in education, is distinguished in an eportfolio of evaluation, presentation- development eportfolio and teaching eportfolio (Abrami \& Barrett, 2005).

As mentioned above, the eportfolio is a form of alternative student assessment. Alternative forms of assessment were developed as opposed to the most restrictive traditional methods, with the main objective of assessing students' attitudes, attitudes and performance on a multifaceted basis. They are original techniques that help students to meet their daily lives, the real life (Paris \& Ayres, 1994), by encouraging reflection and self-assessment and contributing to the development of social and metacognitive skills (Segers, 1999). Alternative assessment has the potential to reverse the traditional pattern of student's passivity by replacing it with initiative, self-discipline and choice (Meyer, 1992), it is included to the formative assessment and is contiguous. It does not substitute other types of assessment, but can be applied alongside them, helping to better capture students' attitudes and performance (Tsagari, 2011).

The main alternative forms of assessment according to Brown \& Hudson's (1998) are: a. the authentic assessment, b. self-assessment, c. assessment using portfolio an eportfolio and d. the descriptive evaluation. Brown (1998), O’Malley \& Pierce (1996), referring to methods (not in forms of alternative evaluation) include among others (Tsagari, 2011) calendars, synthetic works, peer assessment, dramatization, storytelling, counseling meetings, and confrontation.

The difference between alternative evaluation methods and techniques is that techniques are practices that the evaluator can follow and use to arrive at the desired conclusions. According to Janisch, Liu, \& Akrofi (2007), Hoffman, Assaf \& Paris (2001) the alternative evaluation 
includes a series of distinctive features such as:

a). it takes place in the class with teachers to make choices of measures to be used b). it is based on a constructivist view of learning, according to which the student and the content have an impact on the context of the learning outcomes and c). it is based on the view that learning processes are equal, if not longer than the products produced.

Eportfolio is a tool for self-assessment by students. Klafki (1987) emphasizes that the student has the ability to judge, decide, act, according to their own criteria and personal judgement. The use of self-assessment, as well as the development of similar self-esteem skills, is important. According to Koliadis (2002), self-evaluation is an interventional technique through which man can modify his behavior.

In many innovative teachings programs, it is used in addition to very good results in the effort to deepen learning (Matsangouras, 2008). It is the process through which the student is concerned about the quality of his work based on specific criteria and forms (Rolheiser \& Ross, 2001). In other words, the student participates in the designing of the educational process, sets goals, judges and comments (Gros, 2006) and revised accordingly (Andrade \& Valtcheva, 2008). Essentially, students extract their own conclusions about their performance, judging the successes and results of their efforts (Sluijsmans et al., 1999). In conclusion, through self-assessment, the evaluators are given an opportunity to actively participate in the supervision and evaluation of their own progress (Geeslin, 2003). McMillan and Hearn (2008) point out that students should follow three steps (essentially developing three basic skills) that intertwine and influence the process of self-assessment, which are: self-monitoring, self-assessment and choice of learning objectives and corrective activities.

According to Black \& William (1998), Chappuis \& Stiggins (2002), McMillan \& Hearn (2008), through the application of self-assessment the student seeks: a. to become an active participant in the learning process, radically changing his role, b. to develop the skills needed to evaluate his own work, c. to be able to progressively set new goals, feasible for himself as a constant learner, d. to create self-motivation for learning, and e. recognize their learning needs, abilities, and any shortcomings.

The systematic use of self-assessment contributes to the attempt to shape the self-image and to stimulate the student's self-esteem. In order to do this, however, it is necessary to provide students with frequent and effective feedback on their progress (knowledge, behavior, study/work skills) in relation to the existing curriculum (Hendrickson, 2012).

According to the researchers (MacBeath, 2001; Tsagarli-Diamanti, 2003; Parker, 2005; McMillan \& Hearn, 2008), the tools that can be used in self- assessment of the student can be summarized in the following: checklists, self-assessment, -recognition, portfolio - eportfolio, reflection on learning and reflective diary.

\section{Purpose and Research Questions}

The main purpose of this work is to investigate and record the attitudes and perceptions of primary school teachers about the new forms of student assessment as they are imperative in 
contemporary educational reality by researching whether it is feasible to apply the eportfolio as an alternative form of student assessment and as a tool for self - assessment by students. In particular, the work aims at exploring the perceptions and attitudes of respondents regarding: a. the existing system of appraisal of students in elementary school and b. the use of eportfolio as an alternative form of student assessment and as a self - assessment tool by students.

To achieve the above - mentioned specific objectives, the following research questions are arised:

a). What are the attitudes and perceptions of teachers participated in the survey in relation to the existing system of assessment of students in elementary school?

b). What are the attitudes and perceptions of teachers in the research sample regarding the use of the eportfolio as an alternative form of student assessment and as a self-assessment tool by the students?

c). How are the perceptions and attitudes of the teachers of the research sample related to the contribution of the eportfolio as a basic instrument of assessment and self-assessment of the student's course in primary education, as well as the practices that follow regarding the use of modern/alternative forms of assessment in general and more specifically the eportfolio with their personal characteristics?

\section{Method}

The survey was conducted from March to April 2017 using the anonymous written questionnaire method which was completed by 215 primary school teachers of all specialties in the first educational area of Athens. The questionnaire used in this research is improvised and a detailed bibliographic review has been carried out. The questionnaire consists of two (2) parts.

The first part includes general and demographic data of the respondents about the organization of the school, gender, age, years of service in education, years of service in the school now serving, family status, specialty, position at school, qualifications, training and certification in Information and Communication Technology (ICT). In the second part there are eight (8) questions in which teachers are asked to report data related to the use of the eportfolio for the assessment and self- assessment of students.

The statistical analysis was carried out using SPSS v21. The Cronbach's Alpha Index was used to assess the level of reliability of the survey. The reliability analysis performed resulted in a Cronbach Alpha rating of $0.809>0.70$ for all the questionnaire scales, which found that the level of reliability of the research was quite high (Duhachek, Coughlan, \& Iacobucci, 2005; Bryman, 2015).

Concerning the evaluation of the effectiveness of the existing student assessment system this scale consists of six questions graded on a 5 -grade scale, which evaluate the effectiveness of the existing student assessment system. For the first two questions, a higher rating means a more positive assessment for the existing system while the other four have the opposite effect. 


\section{Macrothink}

Therefore, before computing the Cronbachs A score, the answers to the last four questions were re-coded $(1=5,2=4,3=3,4=2,5=1)$. The Cronbach's Alpha Scale $(0.682)$ indicates that the credibility of the scale is questionable. As a result, the researcher must look for ways to improve it. As a result, the height at which the Alpha score will be formed is also calculated by subtracting any of the questions included in the scale. This calculation was made for all questions on a scale. The study of the results shows that by subtracting the last question Cronbach's A score on the scale improves to 0.746. This demonstrates that the rating scale of the effectiveness of the existing student assessment system with 5 questions has an acceptable level of reliability. Then, the height at which the Alpha score will be calculated is calculated by subtracting some of the questions included in the scale. This calculation was made for all questions on a scale. The results show that removing any question worsens the reliability of the scale.

About the contribution of the eportfolio to student assessment and self- assessment the scale consists of seven questions (items) graded on a 5-grade scale, which evaluate the contribution of the eportfolio to the student's assessment and self- assessment. The scale achieved a very high Cronbach's Alpha score (0.905). This demonstrates that the rating scale of the contribution of the eportfolio to the assessment and self-assessment of the student with 7 questions has an excellent level of reliability. Then, the height, at which the Alpha score will be formed, is calculated by subtracting some of the questions included in the scale. This calculation was made for all questions on a scale. The results show that removing the last single question marginally improves the reliability of the scale.

The analysis of the questionnaires was done with correlation tables with appropriate Pearson $r$ controls to see if there are statistically significant differences in the percentages between groups. A statistical significance level of $\mathrm{a}=0.05$ (5\%) was used for the controls. Crosstabs are tested for possible relationships between specific variables.

\section{Results}

\subsection{Sample Teachers' Information}

The clear majority of schools attended by the educators has 12 student sections $(55.3 \%)$, followed by 13 and over (18.8\%) and 11 student sections by $8.4 \%$.

In terms of sex, the majority of the participants are women with $70.7 \%$. The majority of respondents are in the 51-60 age group (37.7\%), followed by those in the category $41-50$ years $(37.7 \%) .41 .4 \%$ of teachers serve in education $11-20$ years and $45.1 \%$ have a service up to 5 years in the current school. $57.2 \%$ of the sample are married and $78.1 \%$ are elementary school teachers.

With a permanent position in the school it serves $80.0 \%$ of the sample, and substitutes are only $9.3 \% .71 .2 \%$ of the respondents have at least one postgraduate degree other than the basic degree, such as Secondary University (27.6\%) and Postgraduate (24.3\%), and 92.1\% have been trained in their subject. $73 \%$ have been certified in New Technologies. $63.7 \%$ have been certified in the A level of Information and Communication Technology (ICT) and only $25.1 \%$ of them have continued to level B of Information and Communication Technology 
(ICT). Finally, 36.1\% of those who have not been certified in the New Technologies have made a good knowledge of New Technologies.

\subsection{First Research Question: Evaluation of the Effectiveness of an Existing Student Assessment System}

To the question "Do you think that the existing student assessment system is the most appropriate one?" the answers of the interviewed teachers are presented in Table 1 below.

Table 1. Appropriateness of the existing student assessment system

\begin{tabular}{lllll}
\hline & Frequency & Percent & Valid Percent & Cumulative Percent \\
\hline Yes & 13 & 6.0 & 6.0 & 100.0 \\
No & 202 & 94.0 & 94.0 & 94.0 \\
Total & 215 & 100.0 & 100.0 & \\
\hline
\end{tabular}

To the question "To what extent do you agree with the following suggestions on student assessment?" the answers of the respondents in relation to specific dimensions of the existing evaluation system, which were asked to evaluate, are presented in Table 2 below.

Table 2. Evaluation of the effectiveness of an existing student assessment system

\begin{tabular}{|c|c|c|c|c|c|c|c|}
\hline$\alpha / \boldsymbol{\alpha}$ & $\begin{array}{l}\text { Evaluation of the } \\
\text { effectiveness of an existing } \\
\text { student assessment system }\end{array}$ & $\begin{array}{l}\text { Totally } \\
\text { agree }\end{array}$ & $\begin{array}{l}\text { Partial } \\
\text { agree }\end{array}$ & $\begin{array}{l}\text { Neither } \\
\text { agree nor } \\
\text { disagree }\end{array}$ & $\begin{array}{l}\text { Partial } \\
\text { disagree }\end{array}$ & $\begin{array}{l}\text { Totally } \\
\text { disagree }\end{array}$ & $\begin{array}{l}\text { Average } \\
\text { Terms }\end{array}$ \\
\hline a. & $\begin{array}{l}\text { the present application of the } \\
\text { assessment gives a clear and } \\
\text { satisfactory picture of } \\
\text { students' abilities and skills }\end{array}$ & $\begin{array}{l}3 \\
1.4 \%\end{array}$ & $\begin{array}{l}61 \\
28.4 \%\end{array}$ & $\begin{array}{l}34 \\
15.8 \%\end{array}$ & $\begin{array}{l}63 \\
29.3 \%\end{array}$ & $\begin{array}{l}54 \\
25.1 \%\end{array}$ & 2.52 \\
\hline b. & $\begin{array}{l}\text { the current implementation of } \\
\text { the assessment responds to the } \\
\text { individual needs of each } \\
\text { student }\end{array}$ & $\begin{array}{l}4 \\
1.9 \%\end{array}$ & $\begin{array}{l}32 \\
14.9 \%\end{array}$ & $\begin{array}{l}39 \\
18.1 \%\end{array}$ & $\begin{array}{l}72 \\
33.5 \%\end{array}$ & $\begin{array}{l}68 \\
31.6 \%\end{array}$ & 2.22 \\
\hline c. & $\begin{array}{l}\text { the current implementation of } \\
\text { the assessment should be } \\
\text { completely changed }\end{array}$ & $\begin{array}{l}59 \\
27.4 \%\end{array}$ & $\begin{array}{l}101 \\
47.0 \%\end{array}$ & $\begin{array}{l}28 \\
13.0 \%\end{array}$ & $\begin{array}{l}22 \\
10.2 \%\end{array}$ & $\begin{array}{l}5 \\
2.3 \%\end{array}$ & 3.87 \\
\hline d. & $\begin{array}{l}\text { the numerical (quantitative) } \\
\text { assessment of students in the } \\
\text { elementary school should be } \\
\text { abolished and only a } \\
\text { descriptive assessment should } \\
\text { be available }\end{array}$ & $\begin{array}{l}70 \\
32.6 \%\end{array}$ & $\begin{array}{l}69 \\
32.1 \%\end{array}$ & $\begin{array}{l}27 \\
12.6 \%\end{array}$ & $\begin{array}{l}36 \\
16.7 \%\end{array}$ & $\begin{array}{l}13 \\
6.0 \%\end{array}$ & 3.68 \\
\hline e. & $\begin{array}{l}\text { alternative forms of student } \\
\text { assessment should be applied }\end{array}$ & $\begin{array}{l}110 \\
51.2 \%\end{array}$ & $\begin{array}{l}85 \\
39.5 \%\end{array}$ & $6.0 \%$ & $\begin{array}{l}6 \\
2.8 \%\end{array}$ & $\begin{array}{l}1 \\
0.5 \%\end{array}$ & 4.38 \\
\hline f. & $\begin{array}{l}\text { student assessment using ICT } \\
\text { can be a reliable form of }\end{array}$ & 23 & 84 & 77 & 20 & 11 & 3.41 \\
\hline
\end{tabular}




\subsection{Second Research Question: Elements of Exploiting the Eportfolio}

To the question "To what extent do you consider that you know about the use of the eportfolio as an alternative/modern form of assessment and self-assessment of the student?" the answers of the respondents are presented in Table 3 below.

Table 3. Knowledge of the eportfolio

\begin{tabular}{lllll}
\hline & Frequency & Percent & Valid Percent & Cumulative Percent \\
\hline Too much & 9 & 4.2 & 4.2 & 100.0 \\
Very much & 15 & 7.0 & 7.0 & 95.8 \\
Enough & 68 & 31.6 & 31.6 & 88.8 \\
A little bit & 82 & 38.1 & 38.1 & 57.2 \\
Not at all & 41 & 19.1 & 19.1 & 19.1 \\
Total & 215 & 100.0 & 100.0 & \\
\hline
\end{tabular}

To the question "If your answer is" Too Much - Enough, "from which did you know the term?" the answers of the teachers interviewed are presented in Table 4 below.

Table 4. eportfolio knowledge sources

\begin{tabular}{lll}
\hline & Frequency & Percent \\
\hline From training sessions & 45 & 21.3 \\
From training seminars & 39 & 18.3 \\
From ICT training & 27 & 12.8 \\
From personal search & 67 & 31.6 \\
From other colleagues & 29 & 13.7 \\
Other & 5 & 2.3 \\
Total & 212 & 100 \\
\hline
\end{tabular}

To the question "Do you have experience of participating in a training program regarding the use of the eportfolio as an alternative / modern form of assessment and self-assessment of the student?" the answers of the teachers interviewed are presented in Table 5 below.

Table 5. Training on the use of the eportfolio

\begin{tabular}{lccc}
\hline Frequency & Percent & Valid Percent & Cumulative Percent \\
\hline & 88 & http://ijld.macrothink.org
\end{tabular}




\begin{tabular}{lllll}
\hline Yes & 35 & 16.3 & 16.3 & 100.0 \\
No & 180 & 83.7 & 83.7 & 83.7 \\
Total & 215 & 100.0 & 100.0 & \\
\hline
\end{tabular}

To the question "To what extent do you consider that you apply the eportfolio as an alternative/modern form of assessment and self-assessment of the student?" the answers of the respondents are presented in Table 6 below.

Table 6. Frequency of application of the eportfolio

\begin{tabular}{lllll}
\hline & Frequency & Percent & Valid Percent & Cumulative Percent \\
\hline Too much & 0 & 0.0 & 0.0 & 0.0 \\
Very much & 4 & 1.9 & 1.9 & 100.0 \\
Enough & 21 & 9.8 & 9.8 & 98.1 \\
A little bit & 64 & 29.8 & 29.8 & 88.4 \\
Not at all & 126 & 58.6 & 58.6 & 58.6 \\
Total & 215 & 100.0 & 100.0 & \\
\hline
\end{tabular}

To the question "To what extent do you consider that the eportfolio, as an alternative / modern form of assessment and self-assessment of the student, is important?" The answers of the respondents are presented in Table 7 below.

Table 7. Significance of the eportfolio

\begin{tabular}{lllll}
\hline & Frequency & Percent & Valid Percent & Cumulative Percent \\
\hline Too much & 12 & 5.6 & 5.6 & 100.0 \\
Very much & 31 & 14.4 & 14.4 & 94.4 \\
Enough & 121 & 56.3 & 56.3 & 80.0 \\
A little bit & 41 & 19.1 & 19.1 & 23.7 \\
Not at all & 10 & 4.7 & 4.7 & 4.7 \\
Total & 215 & 100.0 & 100.0 & \\
\hline
\end{tabular}

To the question "To what extent do you agree with the following suggestions regarding the contribution of the eportfolio to the assessment and the self-evaluation of the student?" The answers of the respondents in relation to the specific proposals which were asked to evaluate are presented in Table 8 below.

Table 8. Degree of contribution of the eportfolio in student assessment and self-evaluation

\begin{tabular}{|c|c|c|c|c|c|c|c|c|c|}
\hline$\alpha / \alpha$ & $\begin{array}{l}\text { Contribution } \\
\text { eportfolio } \\
\text { assessment } \\
\text { assessment }\end{array}$ & $\begin{array}{l}\text { of } \\
\text { to } \\
\text { and }\end{array}$ & $\begin{array}{r}\text { the } \\
\text { student } \\
\text { self- }\end{array}$ & Totally & $\begin{array}{l}\text { Very } \\
\text { much }\end{array}$ & Enough & $\begin{array}{l}\text { A little } \\
\text { bit }\end{array}$ & $\begin{array}{l}\text { Not at } \\
\text { all }\end{array}$ & $\begin{array}{l}\text { Average } \\
\text { Terms }\end{array}$ \\
\hline
\end{tabular}




\begin{tabular}{|c|c|c|c|c|c|c|c|}
\hline & te & & & & & $\begin{array}{r}\text { earning } \\
201\end{array}$ & $\begin{array}{l}\text { Development } \\
2164-4063 \\
\text { l. } 8, \text { No. } 2\end{array}$ \\
\hline \multirow[t]{2}{*}{ a. } & \multirow{2}{*}{$\begin{array}{l}\text { The eportfolio can be applied } \\
\text { as an assessment tool in the } \\
\text { existing educational reality }\end{array}$} & 17 & 42 & 81 & 60 & 15 & 2.93 \\
\hline & & $7.9 \%$ & $19.5 \%$ & $37.7 \%$ & $27.9 \%$ & $7.0 \%$ & \\
\hline \multirow[t]{2}{*}{ b. } & \multirow{2}{*}{$\begin{array}{l}\text { The use of eportfolio is } \\
\text { possible if there is an } \\
\text { integrated training }\end{array}$} & 32 & 81 & 66 & 31 & 5 & 3.48 \\
\hline & & $14.9 \%$ & $37.7 \%$ & $30.7 \%$ & $14.4 \%$ & $2.3 \%$ & \\
\hline \multirow[t]{2}{*}{ c. } & \multirow{2}{*}{$\begin{array}{l}\text { The eportfolio can be an } \\
\text { important alternative to } \\
\text { student assessment }\end{array}$} & 20 & 72 & 82 & 38 & 3 & 3.32 \\
\hline & & $9.3 \%$ & $33.5 \%$ & $38.1 \%$ & $17.7 \%$ & $1.4 \%$ & \\
\hline \multirow[t]{2}{*}{ d. } & \multirow{2}{*}{$\begin{array}{l}\text { The eportfolio can be used as } \\
\text { a self-assessment tool for } \\
\text { students }\end{array}$} & 23 & 60 & 88 & 39 & 5 & 3.27 \\
\hline & & $10.7 \%$ & $27.9 \%$ & $40.9 \%$ & $18.1 \%$ & $2.3 \%$ & \\
\hline \multirow[t]{2}{*}{ e. } & \multirow{2}{*}{$\begin{array}{l}\text { Assessment through } \\
\text { eportfolio can be reliable and } \\
\text { objective }\end{array}$} & 18 & 51 & 105 & 36 & 5 & 3.14 \\
\hline & & $8.4 \%$ & $23.7 \%$ & $48.8 \%$ & $16.7 \%$ & $2.3 \%$ & \\
\hline \multirow[t]{2}{*}{ f. } & \multirow{2}{*}{$\begin{array}{l}\text { Assessment through } \\
\text { eportfolio is directly related } \\
\text { to issues of changing existing } \\
\text { school culture }\end{array}$} & 57 & 82 & 48 & 22 & 6 & 3.77 \\
\hline & & $26.5 \%$ & $38.1 \%$ & $22.3 \%$ & $10.2 \%$ & $2.8 \%$ & \\
\hline
\end{tabular}

\subsection{Third Research Question-Relationship of Perceptions About the Eportfolio and Personal} Characteristics of the Respondents

From the analysis results, statistically significant correlations were identified which are presented and analyzed. More specifically, regarding the contribution of the eportfolio to the assessment and self- assessment of the student, a relatively weak negative correlation $(-0,216)$ was identified in conjunction with age (Table 9). The correlation is statistically significant with a margin of error of less than $0.1 \%(\mathrm{p}<0.001)$ and indicates that older participants tend to give lower scores on this scale. Thus, older educators consider that the eportfolio does not contribute decisively to the students' assessment and self- assessment. 


\section{Macrothink}

International Journal of Learning and Development

ISSN 2164-4063 2018, Vol. 8, No. 2

Table 9. Eportfolio age and estimation contribution scale in student assessment and self-assessment

\begin{tabular}{|c|c|c|}
\hline & & $\begin{array}{l}\text { Scale of contribution of the eportfolio to student } \\
\text { evaluation and self-assessment }\end{array}$ \\
\hline \multirow[t]{3}{*}{ Age } & Pearson Correlation &,$- 216^{* *}$ \\
\hline & Significance(2-tailed) & 001 \\
\hline & $\mathrm{N}$ & 215 \\
\hline \multicolumn{3}{|c|}{ *. Correlation is significant at the 0.05 level (2-tailed). } \\
\hline \multicolumn{3}{|c|}{ **. Correlation is significant at the 0.01 level (2-tailed). } \\
\hline
\end{tabular}

Equivalent results are given by the combination of the same scale with the service years of the respondents (Table 10) with a weak negative correlation (-0.184), statistically significant with a margin of error of less than $1 \%(p=0.007)$. Therefore, teachers who have been in education for many years do not believe that the eportfolio contributes significantly to the learner's assessment and self- assessment (they score low in the overall scale).

Table 10. Relation of years of service to education and the eportfolio's contribution scale in student assessment and self-evaluation

Scale of contribution of the eportfolio to student evaluation and self-assessment

$\begin{array}{ll}\begin{array}{l}\text { Years of service in } \begin{array}{l}\text { Pearson Correlation } \\ \text { education } \\ \text { Significance(2-tailed) }\end{array} \\ \mathrm{N}\end{array} & -, 184^{* *} \\ & 215 \\ * \text {. Correlation is significant at the } 0.05 \text { level (2-tailed). } \\ \text { **. Correlation is significant at the } 0.01 \text { level (2-tailed). }\end{array}$

On the contrary, teachers who have completed more than a basic degree studies believe that the eportfolio can make a lot of contribution to the student's assessment and self- assessment. Thus, they give higher scores on the scale. This is evidenced by a relatively weak positive correlation (0.216), which is statistically significant with a margin of error of less than $1 \%(p$ $=0.002$ ), between the participants' titles and their score on the eportfolio's contribution scale in student assessment and self-assessment (Table 11). 
Table 11. Correlation of study titles and the eportfolio contribution scale in student assessment and self-assessment

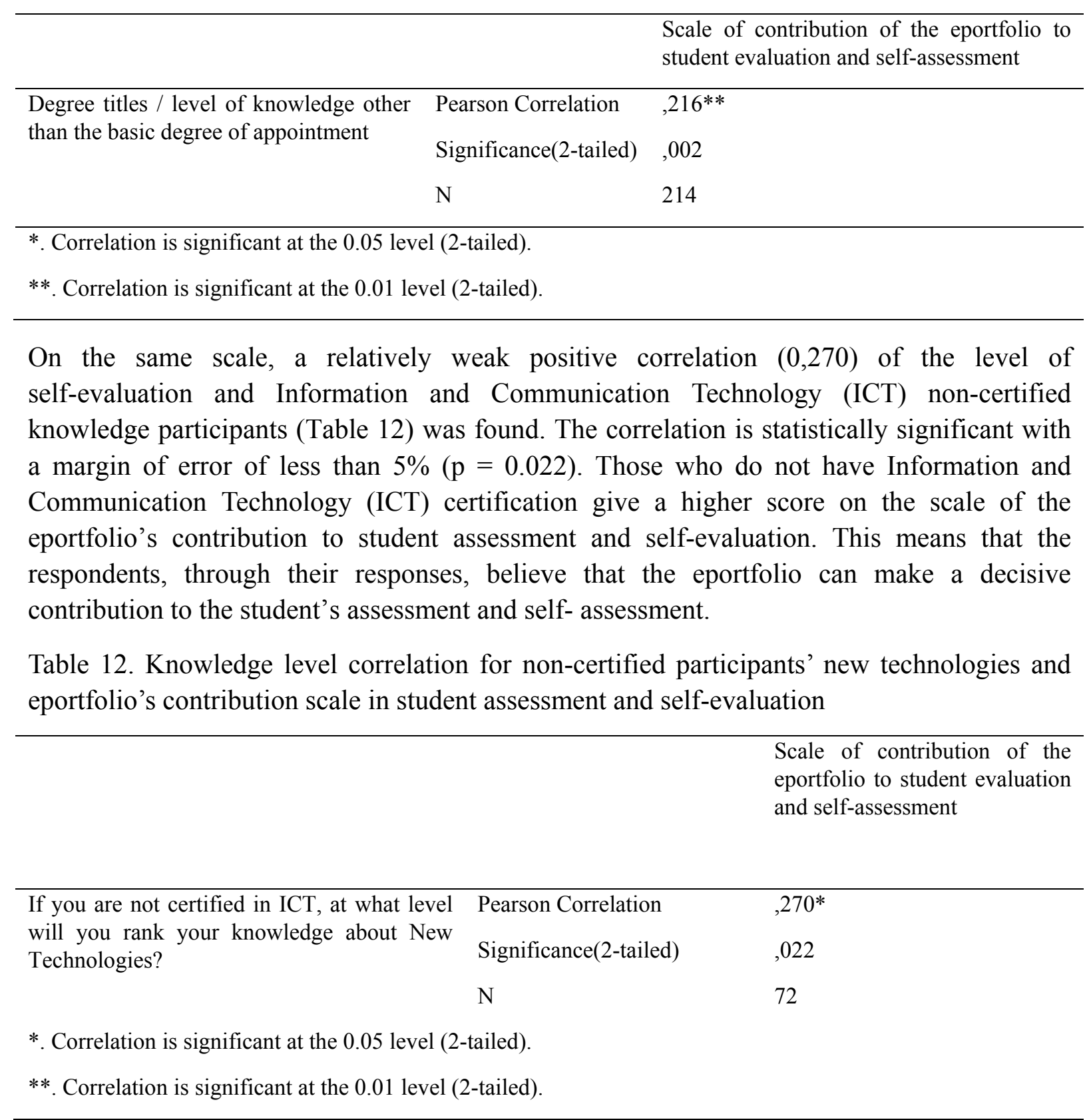

\section{Discussion of Research Results}

Most of the schools attended by the surveyed teachers were $12 /$ student sections with $55.3 \%$, followed by 11 student sections with $8.4 \%$. The percentage of $13 /$ student sections schools and above is $18.8 \%$. In terms of gender, the overwhelming majority of participants are women with $70.7 \%$. In terms of age, the majority is in the 51-60 age group (37.7\%), followed by those in the 41-50 age group (37.7\%). This, of course, means that older educators consider that the eportfolio does not contribute decisively to the student's assessment and self-assessment $\left(-0,216^{* *}, \rho=0,001\right) .41 .4 \%$ of teachers are in education $11-20$ years and 
$45.1 \%$ have up to 5 years in school now. $57.2 \%$ of the sample are married and $78.1 \%$ are elementary school teachers. Also, teachers with many years of service in education do not believe that the eportfolio contributes decisively to the student's assessment and self-assessment $\left(-0.184^{* *}, \mathrm{p}=0.007\right)$. This result is consistent with a survey where older teachers are not familiar with the use of Information and Communication Technology (ICT) (Paulou \& Gouvias, 2007) and runs counter to surveys that state that there is no relationship between age and Information and Communication Technology (ICT) use (Roussos, 2007; Roussos \& Politis, 2004). With a permanent position in the school, it serves $80.0 \%$ of the sample. The retention of teachers in their organic position comes as a natural consequence of the lack of transitions in the first educational area of Athens during the years 2015-2017, as well as of the hypertensions that appear. The deputies are only $9.3 \%$, representing the minimal recruitment of deputies in the first educational area of Athens. $71.2 \%$ of the respondents have at least one postgraduate degree other than the basic degree, such as Secondary University $(27.6 \%)$ and postgraduate $(24.3 \%)$, validating the increase in primary education in the last decade. It is noteworthy that those who hold another degree believe that the eportfolio contributes decisively to the student's assessment and self-assessment $\left(0,216^{*}\right.$, $\rho=0,002$ ). $92.1 \%$ have been trained in their subject and $73 \%$ have also been certified in new technologies. In addition, $63.7 \%$ of the respondents certified in the Information and Communication Technology (ICT) A level and a much lower percentage (25.1\%) continued at Information and Communication Technology (ICT)Level B. 36.1\% of those who have not been certified in new technologies have knowledge of new technologies at a fairly good level, while almost all (72 teachers, 33.5\%) consider that the eportfolio contributes decisively to the student's assessment and self-assessment $0.270 *, \mathrm{p}=0.022$ ).

Regarding the first research question on teachers' perceptions of the existing system of students' assessment in primary school, the overwhelming majority of the sample $(94 \%)$ signify the inadequacy of the existing student assessment system, highlighting its major weaknesses. This view of our teachers is in line with the findings of other relevant surveys (Lamnia, 1999; Konstantinou, 2000; Dochy, 2001). More specifically, with regard to their proposals on student assessment, respondents partly disagree that the present application of the assessment gives a clear and satisfactory picture of students' competences and skills $(29.3 \%)$ and responds to individual needs of each student $(33.5 \%)$, while they partly agree that they should change altogether (47\%). Also, a significant percentage of the respondents (32.6\%) agree with the abolition of the quantitative assessment of students and their substitution by the descriptive assessment, and the same percentage is partly in agreement with this $(32.1 \%)$, while the majority of respondents fully agree that alternative forms of assessment (51.2\%) should be applied. More specifically, with regard to their proposals on student assessment, respondents partly disagree that the present application of the assessment gives a clear and satisfactory picture of students' competences and skills $(29.3 \%)$ and responds to individual needs of each student (33.5\%), while they agree in part that they should change altogether (47\%). Also, a significant percentage of the respondents $(32.6 \%)$ agree with the abolition of the quantitative assessment of students and their substitution by the descriptive assessment, and the same percentage is partly in agreement with this $(32.1 \%)$, while the majority of respondents fully agree that alternative forms of assessment $(51.2 \%)$ 
should be applied. These results are consistent with similar surveys (Meyer, 1992; Paris \& Ayres, 1994; Brown \& Hudson, 1998; Segers, 1999; Vosniadou, Janisch, Liu, \& Akrofi, 2007; Tsagari, 2012) in the evaluation framework will offer many benefits to both teachers and students. With regard to the use of new technologies, fewer than half of the respondents (39.1\%) agree in part that they can contribute to the credibility of the evaluation, with a lower percentage (35.8\%) not clearly stated (and I do not agree, nor do I disagree), pointing out that the way of introducing, incorporating and using new technologies continues to be the subject of study and reflection, while the teacher is undetermined because of the lack of specialized knowledge on the subject (Poupakis, 2001; Rags, 2001). Regarding the second research question on teachers' attitudes and perceptions regarding the use of eportfolio as an alternative form of student assessment and as a tool of self - assessment by students the results are interesting. $19.1 \%$ of the respondents are unaware of the use of the eportfolio as a modern form of student assessment, 38.1\% have little knowledge and $31.6 \%$ have a lot of knowledge. it is remarkable that a significant percentage $(31.6 \%)$ of the 92 respondents who answered the previous question from very much to enough, said they knew the eportfolio from personal search, while only $21.3 \%$ of training days.

The majority of respondents $(83.7 \%)$ do not have any training experience to use the eportfolio as an assessment tool and the majority (58.6\%) do not apply the eportfolio as a tool for alternative assessment and self- assessment of the student. All these are consistent with these surveys (Venn, 2000; McMillan, 2004; Chan, 2009), which point to the need for systematic training by relevant stakeholders on new technologies in general and eassessment in particular (Gaytan \& McEwen, 2009). On the other hand, the lack of knowledge on the subject does not prevent more than half of the respondents $(56.3 \%)$ from responding that the eportfolio as an alternative form of assessment and self-assessment of the student is quite important. This result is consistent with the data from the relevant literature (Segers, 1999; Coutinho \& Bottentuit, 2008b), according to which teachers understand that the eportfolio is an innovative action that contributes to the improvement of teaching methods, learning processes and learning environment. In terms of assessing the contribution of the eportfolio to student assessment and self- assessment, the participants agree that the eportfolio can be applied as an assessment tool to the existing educational reality $(37.7 \%)$, considering that it will be of great help if there is a complete training $(37,7 \%)$. Also, fewer than half $(38.1 \%)$ agree that the eportfolio can be an important alternative to students' assessment, (40.9\%) agree that can be used as a self-assessment tool for students and about half of respondents $(48.8 \%)$ believe that through this the assessment can be reliable and objective. It should be noted that $38.1 \%$ is very much in agreement with the fact that evaluation through eportfolio is very directly connected with issues of change of the existing school culture. This view is in line with the relevant bibliography (Tassi, 2014), which states that teachers should remove prejudices and change their culture of approaching eportfolio (but also of new technologies in general) and appropriate training should be applied? (Doukakis, 2006; Fotopoulou, 2012; Wuetherick \& Dickinson, 2015). 


\section{Conclusions}

Based on the findings of this research and the above analysis we can draw the following conclusions:

a). The overwhelming majority of teachers believe that it is necessary to completely change the existing student assessment system, to implement alternative forms of assessment and to abolish the quantitative assessment.

b). Regarding the using of the eportfolio for the assessment and the self- assessment of the students, the respondents in the overwhelming majority state that they have little or no knowledge of the eportfolio, whereas any knowledge on the subject is mainly due to personal search, or participation in such training.

c). The overwhelming majority of teachers does not apply at all or does little apply the eportfolio, although more than two-thirds of respondents consider it important to apply the eportfolio as an alternative form of assessment and self-assessment of the learner. Also, older educators with many years of experience who have neither degrees, or Information and Communication Technology (ICT)certification, do not render the implementation of the eportfolio important in the educational process.

\section{Limitations}

The above conclusions obviously seem to be subject to further scrutiny and cannot be generalized to the wider educational population due to the constraints imposed by this research. The sample of research is one of the factors that can work to limit the generalization of its results as it comes from a specific geographic and educational area, the sample is little and refers only to primary education teachers in the public sector. However, the findings may be generalized across the whole stuff of the first educational area of Athens due to the size of the sample and its representativeness for the particular region. Also, another restriction is the type of research that was quantitative.

\section{Proposals for Further Research}

Because of this study, several proposals for further research have emerged. More specifically, it is proposed at first to conduct a similar survey on a nationwide scale. Further it is important to have a meaningful longitudinal study ( 3 to 5 years) that explores the specific uses and benefits of collaborative web environments and eportfolios, to apply the eportfolio to all the classes of the elementary school in order to investigate both its effectiveness and the views of the students. Also, future research must be focused on social outcomes such as self-esteem and self-confidence, and ways in which individual and collective creativity can be supported by eportfolio systems. At the end the perceptions of parents and the extent to which society is ready to accept an alternative assessment of students, such as the eportfolio should be researched.

\section{References}

Abrami, P., \& Barrett, H. (2005). Directions for research and development on electronic 
portfolios. Canadian Journal of Learning and Technology, 31(3), 1-15. Retrieved May 26,2018, from https://www.cjlt.ca/index.php/cjlt/article/view/26487/19669

Barrett, H., \& Knezek, D. (2003). Eportfolios: Issues in assessment, accountability and preservice teacher preparation. Paper presented at the American Educational Research Association Conference, Chicago, IL.

Barrett, H. C. (2007). Researching electronic portfolios and learner engagement: The REFLECT initiative. Journal of Adolescent \& Adult Literacy, 50(6), 436-449. Retrieved May 26,2018, from http://electronicportfolios.org/reflect/03-JAAL-50-6Barrett.pdf

Beresford, W., \& Cobham, D. (2011). Undergraduate students: Interactive, online experiences and eportfolio development. Proceedings from IEEE International Conference on Information and Education Technology (ICIET 2011), Guiyang, China. https://doi.org/10.1109/ICCSN.2011.6013825

Black, P., \& Wiliam, D. (1998). Inside the black box: Raising standards through classroom assessment. Phi Delta Kappan, 80(2), 139-148. Retrieved May 26,2018, from https://www.rdc.udel.edu/wp-content/uploads/2015/04/InsideBlackBox.pdf

Brown, D. (1998). New Ways of Classroom Assessment, revised. TESOL Press.

Brown, D., \& Hudson, T. (1998). The alternatives in language assessment. TESOL Quarterly, 32(4), 653-675. Retrieved May 26,2018, from http://www.personal.psu.edu/kej1/APLNG_493/old_site/brown_hudson.pdf

Bryman, A. (2015). Social Research Methods. England: Oxford University Press.

Canada, M. (2002). Assessing e-folios in the online class. New Directions for Teaching and Learning, (91), 69-75. https://doi.org/10.1002/tl.68

Challis, D. (2005). Towards the mature ePortfolio: Some implications for higher education. Canadian Journal of Learning and Technology, 31(3). Retrieved May 26,2018, from https://files.eric.ed.gov/fulltext/EJ1073754.pdf

Chan C. (2009). Assessment: Portfolio,Assessment Resources@HKU. University of Hong Kong.

Chappuis, S., \& Stiggins, J. (2002). Classroom assessment for learning. Educational Leadership, 60(1), 40-43. Retrieved May 26,2018, from http://www.ascd.org/publications/educational-leadership/sept02/vol60/num01/Classroom-Ass essment-for-Learning.aspx

Coutinho, C., \& Bottentuit, J. (2008b). The use of Web 2.0 tools to develop eportfolios in a teacher training program: An exploratory survey. Proceedings of 53th World Assembly of the International Council on Education for Teaching. University of Minho.

Craig, J. (2003). School portfolio development: A teacher knowledge approach. Journal of Teacher Education, 54(2), 122-134. Retrieved May 26,2018, from http://journals.sagepub.com/doi/abs/10.1177/0022487102250286 
Dochy, F. (2001). A new assessment era: different needs, new challenges. Research Dialogue in Learning and Instruction, 10, 11-20. Retrieved May 26,2018, from https://www.sciencedirect.com/science/article/pii/S0959475200000220

Doukakis, S. (2006). The Contribution of Portfolios and Eportfolios to the Teaching of Mathematical Concepts in Lyceum. In V. Katsargyris, E. Panagiotou, A. Demis, C. Milionis, I. Zachos, I. Ligatsikas, \& E. Karagounis (Eds.) The Teaching of Mathematics at the Lyceum. Proceedings of the Scientific Conference (pp. 115-122). Athens, Varvakis School. Retrieved May 26, 2018, from https://sdoukakis.files.wordpress.com/2010/10/sd_portfolios_varvakeios.pdf

Duhachek, A., Coughlan, A. and Iacobucci, D. (2005). Results on the Standard Error of the Coefficient Alpha Index of Reliability. Marketing Science, 24(2), 294-301. https://doi.org/10.1287/mksc.1040.0097

Fotopoulou, C. (2012). EPortfolio as an educational tool in Secondary Education. Diploma Thesis, University of Piraeus. Retrieved May 26,2018, from https://files.eric.ed.gov/fulltext/EJ1107862.pdf

Gaytan, J., \& McEwen, B. (2009). Effective online instructional and assessment strategies. The American Journal of Distance Education, 21(3), 117-132. https://doi.org/10.1080/08923640701341653

Geeslin L. (2003). Student Self-Assessment in the Foreign Language Classroom: The Place of Authentic Assessment Instruments in the Spanish Language Classroom. Hispania, 86(4), 857-868. https://doi.org/10.2307/20062958

Hallam, C., \& Creagh, T. (2010). ePortfolio use by university students in Australia: A review of the Australian ePortfolio Project. Higher Education Research and Development, 29(2), 179-193. https://doi.org/10.1080/07294360903510582

Hendrickson, K. (2012). Assessment in Finland: A Scholarly Reflection on One Country's Use of Formative, Summative, and Evaluation Practices. Mid-Western Educational Researcher, 25(1/2), 33-43. Retrieved May 26,2018, from http://www.mwera.org/MWER/volumes/v25/issue1-2/v25n1-2-Hendrickson-GRADUATE-S TUDENT-SECTION.pdf

Hoffman, V., Assaf, C., \& Paris, G. (2001). High-stakes testing in reading: Today in Texas, tomorrow? The Reading Teacher, 54(5), 482-492. Retrieved May 26,2018, from https://eric.ed.gov/?id=EJ619511

Hsieh, L., \& Chen (2015). Students' Perspectives on Eportfolio Development and Implementation: A Case Study in Taiwanese Higher Education. Australasian Journal of Educational Technology, 31(6), 641-656. Retrieved May 26,2018, from https://www.google.gr/url? sa $=\mathrm{t} \& \mathrm{rct}=\mathrm{j} \& \mathrm{q}=\& \mathrm{esrc}=\mathrm{s} \&$ source $=$ web $\& \mathrm{~cd}=1 \& \mathrm{cad}=\mathrm{rja} \& u a c t=8 \& \mathrm{v}$ ed=0ahUKEwign6Lq6aLbAhUKbVAKHX2jDH0QFggqMAA\&url=https\%3A\%2F\%2Fajet.o rg.au\%2Findex.php\%2FAJET\%2Farticle\%2Fdownload\%2F1605\%2F1320\&usg=AOvVaw2 n9fu1Ym47WYcAohpnCo 
Janisch, C., Liu, X., \& Akrofi, A. (2007). Implementing Alternative Assessment: Opportunities and Obstacles. The Educational Forum, 71, 221-230. https://doi.org/10.1080/00131720709335007

Kelesidis, E., Manafi, I., \& Botsas, G. (2016). Teachers' views of primary education on their training to integrate ICT in teaching with the mixed learning model. Science and Technology Issues in Education, 9(1), 15-29. Retrieved May 26,2018, from http://earthlab.uoi.gr/thete/index.php/thete/article/view/258/133

Klafki, W. (1987). The mission and reform of the elementary school. Pedagogical Review, 6, 47-80. Retrieved May 26,2018, from https://eric.ed.gov/?id=EJ619511

Klampfer, A., \& Köhler, T. (2013). Eportfolios@Teacher Training: An Evaluation of Technological and Motivational Factors. Paper presented at the International Association for Development of the Information Society (IADIS) International Conference on e-Learning, 126-134. Available: Retrieved May 26,2018, from https://files.eric.ed.gov/fulltext/ED562127.pdf

Knight, E., Hakel, D., \& Gromko, M. (2006). The Relationship between Electronic Portfolio Participation and Student Success. Presented at Association for Institutional Research Annual Forum. Retrieved May 26,2018, from https://www.learntechlib.org/p/63672/

Koliadis, E. (2002). Learning Theory and Teaching Practice. Athens: Greek Letters.

Konstantinou, X (1998). School reality and student socialization. Gutenberg - Giorgos \& Kostas Dardanos.

Konstantinou, C. (2000). Assessing student performance as a pedagogical logic and school practice. Athens: Gutenberg.

Landis, M., Scott, S., \& Kahn, S. (2015). Examining the Role of Reflection in ePortfolios: A Case Study. International Journal of ePortfolio, 5(2), 107 - 121. Retrieved May 26,2018, from https://files.eric.ed.gov/fulltext/EJ1107855.pdf

Lorenzo, G., \& Ittelson, J. (2005a). An overview of eportfolios. Educause Learning, Initiative $\begin{array}{lllll}\text { Paper } & 1 . & \text { Retrieved } & \text { May } & \text { 26,2018, from }\end{array}$ https://library.educause.edu/ /media/files/library/2005/1/eli3001-pdf.pdf

Love, T., \& Cooper, T. (2004). Designing online information systems for portfolio-based assessment: Design criteria and heuristics. Journal of Information Technology Education, 3, 65-81. Retrieved May 26, 2018, from https://espace.curtin.edu.au/bitstream/handle/20.500.11937/20020/20234_downloaded_strea $\mathrm{m} \_222$.pdf? sequence $=2 \&$ isAllowed $=\mathrm{y}$

MacBeath J. (2001). Self-evaluation at school. In AE Harisis (ed.), Evaluation of School Learning. Thessaloniki: Kyriakides Brothers.

Maher, M., \& Gerbic, P. (2009). Eportfolios as a pedagogical device in primary teacher education: The AUT University experience. Australian Journal of Teacher Education, 34(5), 
43-53.

Retrieved

May

26 ,

2018

from

http://ro.ecu.edu.au/cgi/viewcontent.cgi?article=1409\&context=ajte

Mason, R., \& Williams, B. (2016). Using ePortfolio's to Assess Undergraduate Paramedic Students: A Proof of Concept Evaluation. International Journal of Higher Education, 5(3), 146-154. Retrieved May 26,2018, from https://files.eric.ed.gov/fulltext/EJ1110284.pdf

McMillan, J., \& Hearn, J. (2008). Student Self-Assessment: The Key to Stronger Student Motivation and Higher Achievement. Educational Horizons, 87(1), 40-49. Retrieved May 26,2018, from https://files.eric.ed.gov/fulltext/EJ815370.pdf

McMillan, J. (2004). Classroom assessment: principles and practice for effective instruction (3rd ed.). MA: Pearson, Boston. https://doi.org/10.28945/1900

McWhorter, R., Delello, J., Roberts, P., Raisor, C., \& Fowler, D. (2013). A cross-case analysis of the use of web-based eportfolios in higher education. Journal of Information Technology Education: Innovations in Practice, 12, 253-286.

Meyer, C. (1992). What's the difference between authentic and performance assessment? Educational Leadership, 49, 39-40. Retrieved May 26,2018, from http://www.ascd.org/ASCD/pdf/journals/ed_lead/el_199205_meyer.pdf

MOSEP - More Self-Esteem with my eportfolio (2007). Grab your future with an eportfolio! Leonardo Da Vinci - the European Program for Vocational Education and Training Pilot project, August 2006 - August 2008. Retrieved May 26, 2018, from http://www.cel.agh.edu.pl/wp-content/uploads/2009/11/mosep_study.pdf

Nikolou, A., \& Georgopoulos, A. (2012). Installation and Utilization of the Mahara Electronic Portfolio in the Educational Process. In Louvris A., Panormos S., \& Fatouros S. (Ed.), Informatics and New School, Proceedings of the 6th Panhellenic Conference of Informatics Teachers, Patras. Retrieved May 26, 2018, from https://sdoukakis.files.wordpress.com/2012/04/na_ga.pdf

Nor Azlan M., Amin E., \& Mohd, N. (2015). Are Students Ready to Adopt Eportfolio? Social Science and Humanities Context. Asian Social Science, 11(13), 269-275. Retrieved May 26,2018, from http://www.ccsenet.org/journal/index.php/ass/article/view/48887/26251

O’Malley, J., \& Pierce, L. (1996). Authentic Assessment for English Language Learning: Practical Approaches for Teachers. New York: Addison-Wesley Publishing.

Papathanasiou, G., \& Manousou, E. (2011). The Student Digital Folder (PSF) as a tool for implementing complementary distance learning school education. Proceedings of the 6th International Conference on Open \& Distance Education, 6, 153-165. Retrieved May 26,2018, from https://sdoukakis.files.wordpress.com/2012/09/pg_me.pdf

Papacharalambous, P. (2008). ELearning support using ePortfolio. Postgraduate Diploma Thesis, Aristotle University of Thessaloniki. Retrieved May 26,2018, from https://sdoukakis.files.wordpress.com/2011/03/2008_papacharalampous.pdf 
Paris, S., \& Ayres, L. (1994). Becoming Reflective Students and Teachers with Portfolios and Authentic Assessment. Washington: American Psychological Association. https://doi.org/10.1037/10158-000

Parker, J. (2005). Should you Encourage Students to Assess Themselves in Practice Learning? A Guided Self-Efficacy Approach to Practice Learning Assessment. Journal of Practice Teaching, 6(3), 8-30. Retrieved May 26,2018, from https://journals.whitingbirch.net/index.php/JPTS/article/viewFile/333/365.

Parker, M., Ndoye, A., \& Ritzhaupt, A. (2012). Qualitative Analysis of Student Perceptions of Eportfolios in a Teacher Education Program. Journal of Digital Learning in Teacher Education, 28(3), 99-107. Retrieved May 26,2018, from https://www.learntechlib.org/p/55484/

Photodentro LOR (Greek National Learning Object Repository). Retrieved May 26,2018, from http://photodentro.edu.gr/lor/?locale $=$ en

Ritzhaupt, A., Singh, O., \& Seyferth, T. (2008). Development of the electronic portfolio student perspective instrument: an eportfolio integration initiative. Journal of Computing in Higher Education, 19(2), 47-71. Retrieved May 26,2018, from https://link.springer.com/article/10.1007/BF03033426

Rolheiser, C., \& Ross, J. (2001). Student self-evaluation: What research says and what practice shows. In Small R. \& Thomas A. (Eds.), Plain talk about kids (pp. 43-57). Covington, LA: Center for Development and Learning.

Roussos, P. (2007). The Greek computer attitudes scale: construction and assessment of psychometric properties. Computers in Human Behavior, 23, 578-590. Retrieved May 26, 2018, from https://pdfs.semanticscholar.org/055c/6c545889fcc0ece126e1a5c3bf553f86299c.pdf

Segers, R. (1999). Assessment in student - centered education: does it make a difference? Uniscene Newsletter, 2, 6-9.

Sluijsmans D., Dochy F., \& Moerkerke G. (1999). Creating a Learning Environment by Using Self- Peer- and Co-Assessment. Learning Environment Research, 1, 293-319. Retrieved May 26, 2018, from https://link.springer.com/article/10.1023\%2FA\%3A1009932704458

Sofos, A., \& Liapi, B. (2007). The Importance of New Technologies and Conceptual Mapping in the Creation of an Eportfolio of Digital Work: A New Challenge. Proceedings of the 4th Pan-Hellenic Conference of ICT Teachers Utilization of Information and Communication Technologies in the Teaching Act. Syros. Retrieved May 26,2018, from https://sdoukakis.files.wordpress.com/2010/11/as_lb_syros_2007.pdf

Sotiropoulos, G. (2012). Utilizing e-Learning with specialized scripts for using the Mahara system in Medical Education. Postgraduate Diploma, National Technical University of Athens. $\quad$ Retrieved $\quad$ May 26, 2018, from https://sdoukakis.files.wordpress.com/2014/01/xp_eportfolios.pdf 


\section{Macrothink}

Strudler, N., \& Wetzel, K. (2005). The diffusion of electronic portfolios in teacher education: Issues of initiation and implementation. Journal of Research on technology in Education, 37, 411-433. Retrieved May 26,2018, from https://www.learntechlib.org/p/98168/ Stylianou, M. (2013). ePortfolio Assessment. Postgraduate Diploma, Open University of Cyprus. Retrieved May 26, 2018, from https://sdoukakis.files.wordpress.com/2014/01/ms_eportfolios.pdf

Tosh, D., Light, T., Fleming, K., \& Haywood, J. (2005). Engagement with electronic portfolios: Challenges from the student perspective. Canadian Journal of Learning and Technology, 31(3), 1-15. Retrieved May 26, 2018, from https://www.cjlt.ca/index.php/cjlt/article/view/26492/19674

Tsagari, D. (2011). Investigating the assessment literacy of EFL state school teachers in Greece. In Tsagari, D., \& I. Csépes (eds.) Classroom-based language assessment (pp. 169-190). Frankfurt am Main: Peter Lang.

Tsoutsou, D., \& Birtsou, S. (2013). An Experimental Study on the Utilization of the E-Portfolio of Primary Education. Proceedings of the 7th Panhellenic Conference of Informatics Teachers, Informatics in Primary and Secondary Education - Challenges and Prospects. Thessaloniki. Retrieved May 26, 2018, from https://sdoukakis.files.wordpress.com/2014/01/dt_sm_eportfolios.pdf

Venn, J. J. (2000). Assessing students with special needs (2nd ed.). Upper Saddle River, NJ: Merrill.

Wade, A., Abrami, C., \& Sclater, J. (2005). An electronic portfolio to support learning. Canadian Journal of Learning and Technology, 31(3). Retrieved May 26, 2018, from http://files.eric.ed.gov/fulltext/EJ1073692.pdf

Wall, K., Higgins, S., Miller, J., \& Packard, N. (2006). Developing digital portfolios: Investigating how digital portfolios can facilitate pupil talk about learning. Technology. Pedagogy and Education, 15(3), 261-273. https://doi.org/10.1080/14759390600923535

Wuetherick, B., \& Dickinson, J. (2015). Why eportfolios? Student Perceptions of ePortfolio Use in Continuing Education Learning Environments. International Journal of ePortfolio, 5(1), 39-53. Retrieved May 26, 2018, from https:/files.eric.ed.gov/fulltext/EJ1107862.pdf

\section{Copyright Disclaimer}

Copyright for this article is retained by the author(s), with first publication rights granted to the journal.

This is an open-access article distributed under the terms and conditions of the Creative Commons Attribution license (http://creativecommons.org/licenses/by/4.0/). 